\title{
SPECIALLY PROTECTED NATURAL AREAS OF REGIONS OF THE SOUTHERN FEDERAL DISTRICT OF RUSSIA: SPECIFICITY OF APPROACHES TO MANAGEMENT
}

AND CONSERVATION

I.V. Mitrofanova, Dr. in Ec. Sc., Professor, Institute of Social, Economic and Humanitarian Researches of the Southern Scientific Center of the Russian Academy of Sciences; Department of World and Regional Economics, Volgograd State University

e-mail: mitrofanova@volsu.ru

G.I. Starokozheva, Ph.D. in Ec. Sc., Associate Professor, Department of State and Municipal Management, Volgograd State University

e-mail: stargala@yandex.ru

E.A. Shkarupa, Ph.D. in Ec. Sc., Associate Professor, Department of Theory of Finance, Credit and Taxation, Volgograd State University

e-mail:shkarupa volsu@mail.ru

V.V. Batmanova, Ph.D. in Ec. Sc., Department of World and Regional Economics, Volgograd State University

e-mail: vbatmanova@mail.ru

I.A. Mitrofanova, Ph.D. in Ec. Sc., Associate Professor, Department of Economics and Management, Volgograd State Technical University

e-mail:mitrofanovaia@rambler.ru

A.B. Tlisov, Ph.D. in Ec. Sc., Associate Professor, North Caucasian Institute - Branch of Russian Presidential Academy of National Economy and Public Administration e-mail: tlisov@mail.ru

\section{Abstract}

It is indispensible to pay a particular attention to the regional aspect of creation, functioning and management of the specially protected natural areas at the study of the natural resource use in the economic districts of Russia and some Russian regions. The share of the net of the specially protected natural areas is $11,7 \%$ of the surface of the Russian Federation. Under the conditions of a new geoeconomic zonation they create their ecological frame, play an important role in the solution of the problems of the conservation of the biological diversity at the process of the accelerating the neo industrialization of the economic life of regions. In these territories the maintenance of the stability of the natural area is provided with the help of special natural use and territory protection regimes. In the article it is shown which types of the specially protected natural areas exist in the Southern Federal District of Russia, their specificity, the specific managerial approaches are analyzed and variants of their modernization are offered.

Key words: Southern Federal District, economic complex, ecological and economic system of the region, biosphere resources, ecological equilibrium, specially protected natural territories, state natural conservation areas, natural parks, state wildlife sanctuaries, natural landmarks, items of World heritage, management mechanism, modernization, efficiency.

\section{Introduction}

An active economic development of biospheric resources has led to a reduction of the surface of natural ecological systems, their fragmentation, imbalance of the structure of species in the biological diversity, destruction of the traditional way of life of indigenous peoples connected with the specific ways of use of natural resources, degradation of lands and desertisation, chemical pollution and a a general reduction of the self-regulating opportunities of the biosphere [Andersson, Ja.O., Eriksson, R. (2010); Common, M., Sigrid, S. (2005); Finger, R., Buchmann, N. (2015); Starokozheva, G.I., Mitrofanova, I.V. (2015) ]. 
The volume of the expenses for the artificial maintenance of an unstable biosphere in a state suitable for the satisfaction of social and economic interests of the mankind and correspondingly for the development of ecological and economic systems can hardly be forecasted. That's why today the specialists in different sciences (ecology, biology, geography, economics, law) undertake numerous attempts of the search of mechanisms (methods and tools) of the prevention and leveling of the consequences of crisis in regional ecological and economic systems. [Greer, J.M. (2011); Kallis, G., Norgaard, R.B. (2010); Mitrofanova, I.V., Starokozheva, G.I., Mitrofanova, I.A., Shkarupa, E.A., Batmanova, V.V (2015); Safronov, A.Ye., Pavlenko, T.S. (2012)]. One of such tools is the creation of the specially protected natural areas.

In the past decade the regional aspect of the creation, functioning and maintenance of the specially protected natural areas gains a considerable attention at the study of nature use problems in economic districts and some regions of Russia. Meanwhile different methods were tested and numerous measures were taken concerning the security and protection of separate natural objects and whole ecosystems [Finger, R, Buchmann, N. (2015); Fredriksson, P.G., Wollscheid, J.R.(2014); Alcott, B. (2012); Murtaza, N. (2011)].

However despite the importance and the obvious necessity the problems of the creation and functioning of the specially protected natural areas always created specific difficulties as they are centered around the change in the total economic value of the natural objects including the value unrelated with their use and the determination of the value of the ecological goods that are not present in the market. Despite that the theory of the balanced development of ecological and economic systems analyses, the availability of such territories as one of the ways of the regulatory actions of the degree of the economic development is one of the forms of the environmental protection.

\section{Literature Review}

The contemporary system of knowledge about the specially protected natural areas developed in the result of the development of different scientific directions: geology, forest science, soil science, land utilization, water use, animal breeding, geography, cultural studies, ethnic groups' history and others. Gradually the idea appeared about the necessity of the isolation of the protective part as one of independent scientific subdivisions dealing with the ways of the efficient and sustainable use of natural resources. The development of the study about the ecological imperative allowed identifying three relatively independent spheres of the study of methods of the practical use of natural resources: efficient industrial use of natural resources or technological aspect; nature protection or limitative or protective part and ecological safety or innovative aspect. A considerable contribution to the development of these aspects was made in the papers of the following scientists: Ja.O. Andersson, M. Common, J.M. Greer, G. Kallis, R.B. Norgaard, S. Stagl.

B. Alcott, N. Buchmann, R. Finger, P.G. Fredriksson., N. Murtaza, J.R.Wollscheid and others influenced substantially the study of specific aspects of the rational natural use. Theoretical and practical aspects of the study of the mechanisms of the provision of the ecologically focused sustainable development of the regions of the Southern Federal District of Russia found its reflection in the publications of the Russian scientists N.T. Avramchikova, G.A. Babkov, T.S. Pavlenko, N.V. Medyanik, I.V. Mitrofanova, L.I. Muratova, A.E. Safronov, G.I. Starokzheva, I.M. Shabunina, M.N. Chuvashova and others. 
The methodological basis of the solution of the scientific tasks became the realization of the dialectic principles of the research within the systematic approach. The authors used general and specific methods of research: subject and object, cultural and functional, historic and logical, comparative, imitational, statistical one and other types of the analysis.

\section{Results}

Parallel to the development of the economic activity the resources run out but the needs grow. A contradiction between the necessity of the involvement of a large number of resources into the production process and the need to keep and to provide an extended reproduction of specially valuable natural objects and resources (as the basis of the future development of the ecological and economic system).

According to the Russian legislation the specially protected natural areas are described as parts of land, water and air above them where the natural complexes and objects having a special natural, scientific, esthetic, recreational, recreational and health importance are located and that are retracted completely or partially form the economic use by the local authorities and for which a special regime of special protection is set ${ }^{1}$.

Such an interpretation reflecting the basic state priorities in the sphere of use of natural resources leave the power to the regions of the Russian Federation to develop concrete mechanisms of management of the specially protected natural areas in regard to their regional specifics [Mikheeva, A.S., Bardakhanova, T.B., Ayusheva, S.N. (2013), Starokozheva G.I. (2013); Murzin A.D. (2012)].

According to the data of the Ministry of Nature of the Russian Federation in the country there were more than 13000 of the specially protected natural areas of the federal, regional and local significance. Their total surface is 211 million hectares or $11,7 \%$ of the surface of Russia. Among them there are 11148 specially protected natural areas of the regional significance, whose total surface makes up 125,8 million hectares (7,3\% of the surface of Russia) and there exist 1598 specially protected natural areas of the local significance and their total surface makes up 27 million hectares $(1,6 \%$ of the surface of Russia) (table 1).

The share of the contemporary net of the specially protected natural areas makes up $11,7 \%$ of the Russian territory. The specially protected natural areas are located geographically within the boundaries of definite regions of the Russian Federation.

In recent decades (20-30 years) the discussion about the regionalization of the problems of the development of the specially protected natural areas as an ecological frame became active under the conditions of the new geoeconomic zoning. Their leading role at the solution of the problems of the biological diversity conservation, at the definition of the ways of making the environment ecological, at the development of territorial complexes, regional economic sectors and the at the assessment of the efficiency of natural resources use is emphasized [Babkov, G.A., Muratova, L.I., Safronov, A.E., Avramchikova, N.N., Chuvashova, M.N. (2014)].

Under the conditions of the systematic crisis, the intensification of the ecological problems, permanent structural reorganization of the system of regional management the specially protected natural areas can become places allowing to realize the complex of activities oriented on the conservation of the ecological equilibrium and to ration the natural use with the help of getting the maximal economic effect.

${ }^{1}$ About the specially protected natural areas: Federal Law dated 14 March 1995. № 33-FZ. URL: http:/ / base.garant.ru/ 10107990/ . 
Table 1. Quantity and surface of specially protected natural areas of Russia (January, 2015)

\begin{tabular}{|l|c|c|c|}
\hline $\begin{array}{l}\text { Category of the } \\
\text { specially protected } \\
\text { natural areas }\end{array}$ & $\begin{array}{l}\text { Number of the } \\
\text { specially protected } \\
\text { natural areas }\end{array}$ & $\begin{array}{l}\text { Surface, } \\
\text { mln. ha }\end{array}$ & $\begin{array}{l}\text { Share of the surface of the } \\
\text { specially protected natural } \\
\text { areas in the territory of } \\
\text { the Russian Fed. }\end{array}$ \\
\hline $\begin{array}{l}\text { Specially protected } \\
\text { natural areas of the } \\
\text { federal level }\end{array}$ & 2 & 3 & 4 \\
\hline $\begin{array}{l}\text { State natural } \\
\text { conservation areas }\end{array}$ & 103 & 58,2 & 2,8 \\
\hline Natural parks & 41 & 45,7 & 1,6 \\
\hline $\begin{array}{l}\text { State wildlife } \\
\text { sanctuaries }\end{array}$ & 71 & 6,9 & 0,4 \\
\hline Natural landmarks & 20 & 13,05 & 0,59 \\
\hline $\begin{array}{l}\text { Specially protected } \\
\text { natural areas of the } \\
\text { regional level }\end{array}$ & 11148 & 0,025 & - \\
\hline $\begin{array}{l}\text { Specially protected } \\
\text { natural areas of the } \\
\text { municipal level }\end{array}$ & 1598 & 125,8 & 7,3 \\
\hline Total & $>13000$ & $>211$ & 1,6 \\
\hline
\end{tabular}

Source: made on the basis of the data: State report "About the condition and the protection of the environment in the Russian Federation in 2014"

http:// http:// www.mnr.gov.ru/ upload/ iblock/ b27/ gosdoklad_2015.pdf).

The growth of number of the specially protected natural areas is not always accompanied by qualitative changes in the development of ecological and economic systems of regions. The introduction of the limitations on the use of land territories and water areas for ecological and economic goals very often leads to the aggravation of the conflict of social and economic interests in the sphere of the land and water use. In most cases the design of the specially protected natural areas and the management of their activity are not connected with the plans of the economic development of both regional territories and adjoining plots of land.

The Southern Federal District of Russia (SFD) consists of three oblasts (regions) (Volgograd oblast, Rostov oblast and Astrakhan oblast), Krasnodar kray an two republics (The Republic of Kalmykia and The Republic Adygeya). The Southern Federal District is located in the South of the European part of Russia, occupies the southern part of the Eastern and European plain, the north west of the Caspian lowland and the western part of the Big Caucasian range. The territory of the Southern Federal District makes up 420.9 thousand square kilometers.

The main specific features of the Southern Federal District are: 1) the transport and geographic position pushes out in the Eurasian part of the country and the position is influenced by the availability of the Volga and Caspian way from the Northern and Central Europe into the countries of the Middle, South Eastern and Southern Asia and also by the Transsiberian Black Sea way connecting the countries of the Asian and Pacific region (China, Korea, Japan) with the countries of the Mediterranean region. The unique transport and transit potential of the Southern Federal District was supposed to become one of the main factors of the development of this macroregion: 1) the most favourable 
natural and climatic conditions and the natural and resource potential for life, recreation and agriculture; 2) the Southern Federal District occupies the third rank among all federal districts after the North Caucasian and Central Federal Districts), has the second rank according to the dynamics of the population (North Caucasian Federal District), has the first rank according to the extent, level and pace of development; 3) significant industrial and production potential occupying the leading positions in the country in some agricultural industries, metallurgy, chemistry, petrochemistry and food industry; 4) large sports and recreation center as well as a transport and infrastructure Sochi Olympic complex that became the catalyst of the social and economic development of the Krasnodar kray and some other regions.

A considerable regional dissimilarity objectively divides the territory of the Southern Federal District into two parts: the Azov and the Black Sea zone and the Volga Caspian region. The Azov and Black Sea region of the Southern Federal District comprises the Krasnodar kray, the Republic of Adygeya and the Rostov region where 9,85 million people live and the density of the population is 53,5 persons per square kilometer. That's why this region has the most favourable natural and climatic conditions as well as social and economic attractiveness for living. The Volgograd and Astrakhan regions have the total population 3,9 million people, the density of the population is 16,4 people per square kilometer (three times lower than in Azov and Black sea region) that shows a considerable distinction between the natural and climatic conditions, social, demographic and economic potential of these two regions of the Southern Federal District.

The Southern Federal District being located mostly in more favourable natural and climatic conditions in comparison with other regions of the country plays an important role in the provision of the food security of the Russian Federation. Here the almost one sixth part of all areas under crops is located where about one fourth of the bulk yield of the crops, a half of the bulk yield of sunflower seeds, one fifth of vegetables yield are gathered. The largest sectors of the economy of the district that have a national and interregional importance are agricultural, tourist and recreational, transport complexes and trade.

The regions of the Southern Federal District count 650 specially protected natural areas that are situated in more than 5,100 thousand hectares. The data of the table 2 prove that such indicators as quantity, surface of the specially protected natural areas, their share in the territory of the corresponding region of the Southern Federal District are heterogenous that help the regions of the Southern Federal District occupy definite ranks in the total list of the regions of Russia according to the given indicators.

Thus, the Rostov region ranks in the first ten regions according to the share of the specially protected natural areas in the total surface of the region $(22,4 \%)$. The biosphere park "Rostovsky" (9,4648 thousand hectares); the national park "Tsimlyansky" $(9,4648$ thousand hectares); the natural park "Donskoy" (40,95513 thousand hectares); 70 natural landmarks $(20,473113$ thousand hectares) and other specially protected natural areas occupying 106,65 thousand hectares are located in the territory of the Rostov oblast (region) ${ }^{2}$. The creation around the state natural conservation area "Rostovsky" of the protection zone of 74,350 thousand hectares can be seen as a unique fact. This is the only state natural conservation area having a larger protection zone than the territory of the whole park.

2 The list of the specially protected natural areas of the regional and local significance within the Rostov region. Updated on 01.01.2015.

http:/ / ecodon.dspl.ru/ docs/ ecofiles/ oopt/ 2001.01.2015.pdf. 
Table 2. Characteristics of the specially protected natural areas of the Southern federal district (January, 2015)

\begin{tabular}{|c|c|c|c|c|c|c|}
\hline $\begin{array}{l}\text { Indicators / } \\
\text { regions of the } \\
\text { Southern }\end{array}$ & $\begin{array}{l}\text { R. } \\
\text { Adygeya }\end{array}$ & $\begin{array}{l}\mathrm{R} . \\
\text { Kalmykiya }\end{array}$ & $\begin{array}{l}\text { Krasnodar } \\
\text { kray }\end{array}$ & $\begin{array}{l}\text { Astrakhan } \\
\text { oblast } \\
\text { (region) }\end{array}$ & $\begin{array}{l}\text { Volgograd } \\
\text { oblast } \\
\text { (region) }\end{array}$ & $\begin{array}{l}\text { Rostov } \\
\text { oblast } \\
\text { (region) }\end{array}$ \\
\hline
\end{tabular}

Federal District

The share of

3,34

14,52

6,63

5,51

8,74

22,04

the the

specially

protected

natural area of

the surface of

the region,

$\%$

Rank of the

region in the

total list of the

Russian regions

Surface of the

the specially

protected

natural area,

thousand

hectares

Rank of the

region in the

total list of the

( 12 )

(48)

( 53 )

( 34 )

$26 \quad 1084,72 \quad 500,72$

291,62

986,68

2

regions of

Russia

Number of the

18

23

423

49

$53 \quad 80$

the specially

protected

natural areas

Rank of the

region in the

total list of the

regions of

Russia

Source: made on the basis of the data: State report "About the condition and the protection of the environment in the Russian federationin 2014"

http:// http:/ / www.mnr.gov.ru/ upload/ iblock/ b27/ gosdoklad 2015.pdf).

The Krasnodar kray ranks in the first ten regions according to the indicator of the quantity of the specially protected natural areas located in the territory of the region. The system of the specially protected natural areas in the region comprises one state natural conservation area, one national natural park, sixteen wildlife sanctuaries and more than four hundred natural landmarks and thirty four recreation and health zones. 
More than four hundred natural landmarks of the Krasnodar kray are presented by unique plots of rare and relict plantations, lakes, caverns, water falls and other landscape and botanic places ${ }^{3}$.

The total surface of the specially protected natural areas makes up 428,69 thousand hectares. In the lower reach of the Volga river in the Astrakhan oblast (region) there are four natural regions differing from one another in landscape, composition of the flora and the fauna, structure of the vegetable and animal world, ecological conditions. They are the Volga river delta, the Volga and Akhtuba flood plain, the western State Natural Reserve "Ilmenno-Bugrova" and the area of deserts and half-deserts 4.

In the territory of the Astrakhan oblast (region) there exist two state natural wild life sanctuaries of the federal importance (Astrakhan biosphere wildlife sanctuary and Bogdinsko-Baskunchak wildlife sanctuary), there are 49 specially protected natural areas of the regional significance. According to categories there are two national parks: "Volga and Akhtuba interstream area", "Baskunchak"; four national state wild life sanctuaries: "Vyazovskaya dubrava", "Ilmeno-Bugorva", "Stepnoy", "Peski Berli"; eight state biological wild life sanctuaries: "Teplushki", "Ikrianinsky", "Mininsky", "Krestovy", "Zhirotopka", "Bukhovsky", "Kabaniy", "Yenotayevsky"; 35 natural landmarks of the regional significance. Every place is unique and valuable in its own way.

The specially protected natural areas in the republic of Kalmykia are: 1) The State natural biosphere sanctuary "Cherniye zemli" (121,900 hectares), was created for the study of the steppes, half desert, desert landscapes and also for the protection and the study of the Kalmyk population of the Saigak antelope; 2) "Natural Park of the Republic of Kalmykia" (4,323 hectares) where the biotopes (willow, poplar forests, lakes and marshes, bottomland lowlands, shallow channels of yeriks, flood plain sands) that are unique for Kalmykia are presented; 3) twelve national wild life sanctuaries three of which are of federal significance and nine are of the republican belonging5; 4) three natural landmarks ${ }^{6}$.

The table 3 provides the information about the number of the specially protected natural areas in the regions of the Southern Federal District of different categories according to the federal legislation 7 . In the district there are seven state natural biosphere wild life sanctuaries, two national parks, fifty natural wild life sanctuaries, five hundred and seventy four natural landmarks, thirty five recreational and health places and resorts.

Besides in the territory of the Southern Federal District there are eight objects of the World Heritage, three of which are located in the Krasnodar kray. They are the Caucasian state natural biosphere wild life sanctuary and two areas or water and marshes territories of international significance that were created in order to implement the

3 About specially protected natural territories of the Krasnodar kray. URL: http:// mprkk.ru/ prirodnyie-resursyi-i-ohrana-okruzhayuschej-sredyi/ osobo-ohranyaemyie-prirodnyieterritorii/ osobo-ohranyaemye-prirodnye-territorii/ ob-osobo-ohranyaemyh-prirodnyhterritoriyah-krasnodarskogo-kraya/ .

4 The Department of the natural use and environmental protection of the Astrakhan region. Regional specially protected natural territories. URL: https:/ / nat.astrobl.ru/ stranica-sayta/ regionalnye-oopt. 5 Department of Natural Resourced and Environmental Protection of the Republic Kalmykia. (URL: http:/ / www.kalmpriroda.ru/ oos_oopt.html).

${ }^{6}$ In 1970s in Kalmykia there were 22 natural landmarks of the regional significance. However many objects lost in course of time their environmental importance, their status was revised and the list of the natural landmarks was considerably shortened.

7 About the specially protected natural areas: Federal Law dated 14 March 1995. № 33-FZ. URL: http:/ / base.garant.ru/ 10107990/ . 
commitment of the Russian Federation resulting from the Ramsar Convention ${ }^{8}$ : «The group of sited estuaries between the Kuban River and the Protoka river », "AkhtaroGrivenskaya system of sited estuaries».

Table 3. Number of the specially protected areas in the regions of the Southern Federal District according to categories mentioned in the Law "About the specially protected natural areas"

Indicators /

R.

regions

$\begin{array}{lll}\text { R. } & \text { R. } & \text { Krasnodar } \\ \text { Adygeya } & \text { Kalmykiya } & \text { kray }\end{array}$

Astrakhan

oblast

(region)
Volgograd
oblast
(region)

Rostov

oblast

(region)

conservation

areas, including

biosphere ones

National parks

Natural parks

State natural wil

life sanctuaries

Natural

landmarks

Health and

Recreation places

and Resorts

Items of the

World Heritage
2

1

2

1

1

1

1

1

30

12

9

16

405

12

36

34

7

8

15

77

Source: made on the basis of the data: State report "About the condition and the protection of the environment in the Russian federation in 2014". (URL: http:// http:// www.mnr.gov.ru/ upload/iblock/ b27/gosdoklad 2015.pdf); About the specially protected natural areas: Federal Law dated 14 March 1995. № 33-FZ. (URL: http:/ / base.garant.ru/10107990/); The list of the specially protected natural areas of the regional and local significance within the Rostov region. Updated on 01.01.2015. (URL: http:// ecodon.dspl.ru/ docs/ ecofiles/oopt/2001.01.2015.pdf); About specially protected natural territories of the Krasnodar kray. (URL: http:// mprkk.ru/prirodnyie-resursyi-i-ohrana-okruzhayuschej-sredyi/ osoboohranyaemyie-prirodnyie-territorii/ osobo-ohranyaemye-prirodnye-territorii/ ob-osobo-ohranyaemyhprirodnyh-territoriyah-krasnodarskogo-kraya/); Specially protected natural areas of the Republic of Adygea (URL: http:/ / adygcomtur.turometr.ru/blog/4045.html); The list of the specially protected natural areas of the Volgograd region. (URL: http:// oblkompriroda.volganet.ru/ other/ protected/); The Department of the natural use and environmental protection of the Astrakhan region. Regional specially protected natural areas. URL: https:// nat.astrobl.ru/ stranica-sayta/regionalnye-oopt; Department of Natural Resources and Environmental Protection of the Republic of Kalmykia. (URL: http:/ / www.kalmpriroda.ru/ oos_oopt.html).

For a sustainable development of the object of the World Heritage "Western Caucasus" the recreational activity was initiated in the most favourable places in the Republic of Adygea: Lagonakskoye highlands, region of the mountain Bolshoy Tkhach, upper reach of the river Pshekha, canon of the river Kurdzhips and the natural landmark "Khrebet Buyny" 9.

Other type of the category of the specially protected natural territories can also be suggested. For instance they can be territories where the monuments of the park and garden art are situated, the protected coastal lines, the protected river systems, the protected natural landscapes, biological stations, micro wild life sanctuaries and so on.

8 «Ramsar Convention» или «The Convention on Wetlands of international importance as a birdlife International » (Рамсар, 2 февраля 1971 г.). URL: http://www.ex-situ.ru/documents/ 105ramsarskaya-konventsiya

9 The Specially protected natural areas of the Repulic of Adygea. URL: http:/ / adygcomtur.turometr.ru/ blog/ 4045.html. 
The Government of the Russian Federation, the corresponding regional and local authorities have the right to assign the mentioned above categories.

Thus, by the decision of the regional authorities of the Volgograd region eight areas having a special significance for the conservation of the species of the animal and plant world included into the "Red List (the list of the endangered species) of the Volograd region" were settled»10.

The Law "About the specially protected territories areas of the Krasnodar kray"11 stipulates the following categories: state zoological wild life sanctuaries, water and marshes areas, arboretums, botanic gardens, wild life sanctuaries for the internal use, water protecting areas and coastal protecting areas and urban parks.

The specially protected natural areas in the Southern Federal District have different levels of significance. The state national natural wild life sanctuaries including the biosphere and national parks are considered as objects of the federal significance are located in the territories of almost all the regions of the Southern Federal District. Their total number is nine. Besides in the Krasnodar kray, the republic of Kalamykia, the Rostov oblast (region) have nine state natural wild life sanctuaries of the federal significance. Such territories are the federal property and are controlled and managed by the federal authorities.

A large number of territories of the state wild life sanctuaries, natural landmarks, dendrological parks, natural parks, botanic gardens, health and recreational areas and resorts in the Southern federal district have the status of the specially protected national areas of the regional significance and are the property of regions and are controlled and managed by regional authorities.

The status of the specially protected natural territory of the federal or regional significance is determined by the Government of the Russian Federation and the regional authorities. Some health and recreation areas and resorts, more than seventy natural landmarks are the specially protected areas of local significance are owned by municipalities and are controlled and managed by local authorities. Their status is established by the order determined by the law and other normative act of the regions of the Russian Federation.

Independently from the status, the specially protected natural areas are taken into analysis when developing territorial complex schemes, the plans of land utilization and regional planning of territories within geographic areas where they are situated. Very often within one municipality there can be the specially protected natural areas of the federal, regional and local level consequently. That's why the management of the specially protected natural areas, the development of their geographical net is expected to be based on the imperatives of a more rational interaction of all interested parties: authorities, business, science and society ${ }^{12}$.

It is obvious that the availability in the territory of municipal regions of the southern regions of Russia of the specially protected natural areas of different status and categories requires from the local authorities the regulation of the economic activity taking into consideration the presence of such territories and regimes of functioning of

10 The list of the specially protected natural areas of the Volgograd region. URL: http:/ / oblkompriroda.volganet.ru/ other/ protected/ .

11 About the specially protected natural areas of the Krasnodar kray: law dated March, 4th 1998 119KZ. URL: http:/ / sochi.news-city.info/ docs/ sistemss/ dok ieyyio.htm.

12 The Conception of the development of the system of the specially protected natural areas for the period till 2020: decree of the Government of the Russian Federation dated December, 22 2001. № 2322-p. URL: http:/ / base.garant.ru/ 70116598/ \#block_1000. 
each of them. When managing the specially protected natural areas it is indispensible to know the methods of regulating the activity of the whole net located in the territory of the administrative division.

Such supposition allows isolating two groups and several management mechanisms of the specially protected natural areas of the regional significance taking into account the status of these territories. The first group includes the municipal, regional and federal managerial types in the cases when within one region there are objects only of the federal, regional and municipal property.

The second group comprises four mixed types of management in dependence on the combination of the statuses of the specially protected natural areas located within the borders of the administrative territory of a region. Thus the first type of management that is displayed here is the municipal and regional one, the second managerial type is the municipal and federal one, the third managerial type is the regional and federal one, the fourth managerial type is the municipal and regional and federal one.

The realization of the mixed managerial type by the local authorities is extremely complicated without the creation of external structures providing the strategic and current management of the specially protected natural areas of all types of all statuses. The most ecologically vulnerable or considerable in social and economic regard fields should be isolated as the sectors meant for management. In contrast to other approaches in this case a special, "pansectoral", non-departamental sectoral authority is created [Murzin, A.D. (2012); Starokozheva, G.I. (2013); Medyanik, N.V. (2013)].

It is worth mentioning that in the territories of the municipal districts of the regions of the Southern Federal District the specially protected natural areas with different statuses and different categories are created. Besides they are located unevenly in administrative units that makes the process of the development of the efficient mechanisms of the specially protected natural areas more complicated.

If we stand by the idea of the ecological and economic balance of the managerial decisions within the geographic limits of the specially protected natural areas, so the creation of external interregional or supraregional managerial authorities of the specially protected natural areas could level the negative tendencies in the process of the choice of the economic preferences providing the implementation of the most efficient projects.

\section{Conclusion}

The specially protected natural areas in the Southern Federal District of Russia were created for the lowering and sometimes for the elimination of the anthropogenic load on the natural components, complexes, development of the ecological tourism and competent use, conservation and recovery of natural resources. In these territories the sustainability of the natural environment with the help of the introduction of special regimes of the natural use and territorial protection is provided.

But the modern condition of the regional nets of the specially protected natural areas in the Southern Federal District makes think about the expedience of the available statuses for many objects that lost interest from the point of view of the initially determined characteristics and functions (eroded lands, poor value field protecting forest belts and so on). A number of unique natural complexes and objects (including those who got the status of "natural parks" in 2000-2015) turned out to be either beyond the limits of the specially protected natural areas or according to the complex of indices do not correspond to the established status (legal statute). In a number of places the final statement of the ecological expertise is absent. In the process of the external and internal zoning the economic methods of the natural resources assessment were not used. 
For the available approaches to the management of the specially protected natural areas the constant revision of the lists of the objects with regional and municipal statuses, the absence of the practice of development and introduction of management plans of development, the funding mainly using the money from the budgets from all levels without attracting the market instruments is typical.

The modernization of the managerial mechanism by regional nets of the specially protected natural areas is possible only at the use of the authentic information that will allow maximally approaching the optimal value when comparing.

The monitoring assessment of the condition of the specially protected territories in the Southern Federal District is needed. Such an assessment can be executed in the process of the inventory of the nets of the specially protected natural areas. The traditional procedures allow specifying the available cadastre information or get the additional one, allow displaying the presence or the absence of indices according to which the category of the territory and the indices according to which the transfer of one category to another is possible, allow taking decisions about the alternative ways of the development of the specially protected natural areas or the use of market mechanisms for their development within the given status of the area.

In order to specify the status and the category of the specially protected natural area together with the traditional procedures in course of the inventory it is indispensible to find and to assess in absolute or relative values the factors that mainly influence the decisions about the opportunity of the economic development of natural objects and values that are not connected with their use.

The importance of use of the mentioned approach is obvious also in the practice of the strategic territorial management when using the specific tool or interregional programs. Such programs expand their activity on the regions form two or three adjoining economic regions. In the course of their realization the strategic tasks are connected, for instance, with the conjoint development and use of large scale natural resources; creation of the conditions for the provision of the sustainability, ecological and economic security of the subjects of the federation [Mitrofanova, I.V., Starokozheva, G.I., Mitrofanova, I.A., Shkarupa, E.A., Batmanova, V.V. (2015); Safronov, A.Ye., Pavlenko, T.S. (2012)].

All the mentioned above suggestions do not contradict the Conception of the improvement of the state management of the specially protected natural areas ${ }^{13}$ that implies the creation of the coordination centers and the organization of the scientific, enlightening, ecological and tourist, educational, design and survey activity, informational and analytical activity. The Convention also assumes the creation of expert councils, the reorganization of the system of some specially protected natural areas by means of their reorganization, the introduction of the system of the development of middle term plans for the management of the specially protected natural areas, the introduction of the auditing systems. The realization of these suggestions will allow modernizing the institutional, organizational, financial and economic approaches to the management of the specially protected natural areas of the Southern Federal District of Russia.

\section{References}

Andersson, Jan Otto and Ralf Eriksson. 2010. Elements of Ecological Economics. New York:Routledge:164 p.

13 The Conception of the development of the system of the specially protected natural areas of the federal significance for the period till 2020: decree of the Government of the Russian Federation dated 22th December 2011. № 2322-p. URL: http:/ / base.garant.ru/ 70116598/ \#block_1000. 
Common, Michael and Sigrid Stagl. 2005. Ecological Economics: An Introduction. Cambridge, UK: Cambridge University Press: $592 \mathrm{p}$.

Greer, John Michael. 2011. The Wealth of Nature: Economics as if Survival Mattered. Gabriola Island, BC: New Society Publishers: $288 \mathrm{p}$.

Kallis, Giorgos and Norgaard Richard B. 2010. Coevolutionary ecological economics. Journal Ecological Economics - ECOL ECON. Vol. 69, 4: 690-699.

Finger, R., Buchmann, N. 2015. An Ecological Assessment of Risk Reducing Effects of Species Diversity in Managed Grasslands / / Ecological Economics. Vol. 110: 89-97.

Fredriksson P.G., Wollscheid J.R. 2014. Environmental and Political Centralization // Ecological Economics. Vol. 80: 109-120.

Murtaza N. 2011. Pursuing Self-Interest or Self - Actualization? From Capitalism to a Steady-State, Wisdom Economy // Ecological Economics. Vol. 70: 577-584.

Mitrofanova I.V., Starokozheva G.I., Mitrofanova I.A., Shkarupa E.A., Batmanova V.V. 2015. Ecological External Effects of the Funcitioning of the Economic Complex of the South of Russia / / Regional and Sectoral Economic Studies. 2015. Vol. 15-1: 97-114.

Starokozheva G.I., Mitrofanova I.V. 2015. The Environmental "cost" of Doing Business in the Southern Federal District // Regionalnaya ekonomika. Yug Rossii [Regional Economy. South of Russia]. 2015. 2(8): 25-35.

Avramchikova N.T., Chuvashova M.N. 2014. Problemy povysheniya kachestva ekonomicheskogo prostranstva v resursno-orietntirovannykh regionakh Rossiyskoy Federatsii [The problems of the quality increase of the economic space in the resource centered regions of the Russian Federation] // Regionalnaya ekonomika: teoria i praktika [Regional economics: theory and practice]. 2014. 5: 2-11.

Safronov A.Ye., Pavlenko T.S. 2012. Ratsionalnoye ispolzovaniye prirodno-ekonomicheskogo potentsiala regiona [Rational use of the natural and economic potential of the region]// Regionalnaya ekonomika. Yug Rossii [Regional Economy. South of Russia]. 2012. 13: 463-469.

Babkov G.A., Muratova L.I., Safronov A.Ye. 2013. Otsenka I ispolzovzniye prirodno-ekonomicheskogo potentisala regionalnoy ekonmiki [The assessment and use of the natural and economic potential of the regional economy] // Regionalnaya ekonomika. Yug Rossii [Regional Economy. South of Russia]. 2013. 2: 30-36.

Murzin A.D. 2012. Kompleksnaya otsenka sotsio-ekologo-ekonomicheskikh faktorov sostoyaniya urbanizirovannykh territoriy // Regionalnaya ekonomika: teoria i praktika [Regional economics: theory and practice]. 2012. №8: 44-50.

Starokozheva G.I. 2013. Osobo okhraniayemiye prirodnye territorii Yuzhnogo fedealnogo okruga: sovershenstvovaniye mekhanizma upravlenia [The specially protected natural areas of the Southern Federal District: improvement of the managerial mechanism] // Regionalnaya ekonomika. Yug Rossii [Regional Economy. South of Russia]. 2013. 2013.2: 163-169.

Medyanik N.V. 2013. Protivorechiya razvitiya prirodokhoziaystvennykh system regionov Yuga Rossii [Contradictions of the development of natural and economic systems of the regions of the South of Russia] // The proceedings Sworld. 2013.3(39): 79-82.

Lipina S.A. 2013. Sotsialnaya meditsina i zelenaya ekonomika: forsait ekotekhnologiy [Social medicine and the "green economy": foresight of the ecological technologies]// Regionalnaya ekonomika. Yug Rossii [Regional Economy. South of Russia]. 2013. 2: 84-89.

Mikheeva A.S., Bardakhanova T.B., Ayusheva S.N. 2013. Regionalniye osobennosti formirovaniya ekologoorientirovannoy investitsionnoy politiki na territoriakh s ekologicheskimi ogranicheniyami [Regional specificity of formation of the ecologically focuses investment policy in the territories with ecological limitations]// Regionalnaya ekonomika: teoria i praktika [Regional economics: theory and practice]. 2013. 27: 2-7.

RGE: http:/ / www.usc.es/ econo/ RGE/ benvidag.htm 